\title{
A Pragmatist Dimension in Georg Henrik von Wright's Philosophy
}

\author{
Sami Pihlström \\ Helsinki Collegium for Advanced Studies, \\ University of Helsinki \\ P.O. box 4 (street address: Fabianinkatu 24), \\ Helsinki 00014, Finland \\ E-mail: sami.pihlstrom@helsinki.fi
}

\begin{abstract}
This paper reconsiders Georg Henrik von Wright's theory of causation from the point of view of pragmatism. Given the conceptual link between causation and action, von Wright's position might be reinterpreted along pragmatist lines, even though he never explicitly developed his views with reference to pragmatism. However, the dichotomy between the ontological and the conceptual presupposed by von Wright may also be criticized from a pragmatist perspective.
\end{abstract}

Keywords: action, causation, freedom, Georg Henrik von Wright, pragmatism

\section{Introduction}

Ludwig Wittgenstein's relation to the tradition of pragmatism has received increasing attention over the past few years. For instance, Russell Goodman devoted a monograph to Wittgenstein's links with William James already more than a decade ago (Goodman, 2002); more recently, the open access online journal European Journal of Pragmatism and American Philosophy published a special issue on this topic. ${ }^{1}$

In my own recent attempt to (re-)connect Wittgenstein with pragmatism (Pihlström, 2012), I discuss, from a pragmatist perspective, three key issues of Wittgenstein studies that provide useful insights into the ways in which Wittgenstein, or the contemporary "Wittgensteinian" philosopher, may be said

1 Vol. 4, no. 2 of this journal also contains an essay of my own (Pihlström, 2012). The present paper can be read as an extension of that inquiry to post-Wittgensteinian philosophy; see http://lnx.journalofpragmatism.eu/. 
to be a pragmatist: firstly, the distinction-invoked in recent discussions of Wittgenstein's On Certainty, in particular-between the propositional and the nonpropositional; secondly, the related tension between anti-Cartesian fallibilism and what has been called the "truth in skepticism" in Wittgenstein; as well as, thirdly, the relation between metaphysics and the criticism of metaphysics in Wittgenstein's philosophy, and Wittgensteinian philosophy more generally. I there argue that dichotomous readings of Wittgenstein in terms of these three philosophical (or metaphilosophical) oppositions lead to unpragmatist and even un-Wittgensteinian positions. I then proceed to a more explicitly metaphilosophical consideration of a fourth, equally harmful dichotomy, the one between deconstructive (therapeutic) and (re)constructive or systematic, argumentative philosophy — which is, we may argue, again something that the pragmatist, together with Wittgenstein, ought to overcome rather than rely on. These issues are, and largely remain, open and debated questions in Wittgenstein scholarship; the pragmatist perspective on them may be regarded as one interesting, though by no means a conclusive, voice in the debate. ${ }^{2}$

Among Wittgenstein's many pupils and followers, Georg Henrik von Wright, Wittgenstein's successor as the holder of his Chair at the University of Cambridge, was one of the most original and influential ones. Arguably, von Wright, who studied in Helsinki and returned to Finland after his period in Cambridge in 1951, was by far the leading Baltic Sea region thinker influenced by Wittgenstein-and clearly one of the most significant Baltic Sea region philosophers more generally. His philosophical work is, generally speaking, farther away from pragmatism than Wittgenstein's own, but there are some interesting possibilities of establishing a link between von Wright and pragmatism, too. ${ }^{3}$ We should thus take a brief look at some von-Wrightian themes in order to sketch an example of postWittgensteinian philosophy that is not at all explicitly pragmatist but contains

For my more general approach to pragmatism, also considering the relation between pragmatism and other contemporary philosophical orientations, see, e.g., Pihlström, 2011. In this paper, I would not even attempt to define pragmatism; it is sufficient to note that it is a philosophical tradition originated by philosophers such as Charles S. Peirce and William James in late nineteenth-century United States, seeking to examine the true meaning of philosophical and scientific concepts in terms of the potential practical effects of their objects. That there may be some pragmatist tendencies in philosophers like Wittgenstein and von Wright is unsurprising; what may be more interesting is the specific way those tendencies are at work in their thought which generally cannot be classified as pragmatist.

3 Von Wright only rarely commented explicitly on pragmatism. However, already in his early work on logical empiricism published in Swedish (von Wright, 1943), he did acknowledge both Peirce and James as precursors of logical empiricism - a simplified view of pragmatism, of course, but understandable in its context as characteristic of logical empiricism. It might be noted that in the index of the 942-page tome, The Philosophy of Georg Henrik von Wright (Schilpp \& Hahn, 1989), there is not a single reference to pragmatism, although there are some scattered references to Peirce and James in some of the contributions, including especially Hartshorne (1989). 
pragmatic tendencies. Note, however, that I am not going to discuss von Wright as an interpreter (and editor) of Wittgenstein's works here, even though his essay "Wittgenstein on Certainty", one of the earliest interpretations of On Certainty, emphasizes precisely the kind of picture of pragmatic certainties-in-action that has been discussed in readings of the "third Wittgenstein". ${ }^{4}$

\section{Action and causation}

Von Wright's philosophy of action and the related theory of causation are obviously our most important points of emphasis here. We should, however, start by noting that von Wright's well-known theory of action is not particularly pragmatist because it primarily considers individual actions rather than continuous habits of action; the latter instead of the former would be in the focus of a paradigmatically pragmatist approach to action theory. However, there are four areas in which we may view von Wright's philosophy as "pragmatist" in a broad sense. I am not claiming that these four areas exactly correspond to the four dimensions of the Wittgenstein-pragmatism comparison listed in the introduction (and more comprehensively discussed in Pihlström, 2012); yet, it is clearly possible to see a loose parallel, or an analogy. This analogy should be investigated in more detail than is possible here.

First, von Wright $(1971 ; 1974)$ famously_or, according to some, notoriouslydefends a theory of causation essentially linked with the concept of action. $\mathrm{He}$ labels this theory "actionist", "manipulative", and "experimentalist", suggesting that the notion of cause is "essentially tied to the idea of action and therefore, as a scientific notion, to the idea of experiment" (von Wright, 1971, pp. 3637; cf. pp. 189-190; see also von Wright, 1974, p. 57). ${ }^{5}$ While admitting that etymology is not decisive here, he also refers to the link between the concepts of cause and guilt captured by the corresponding words in classical languages (as well as Finnish) (von Wright, 1971, pp. 64-65). Regardless of etymology, "we cannot understand causation, nor the distinction between nomic connections and accidental uniformities of nature, without resorting to ideas about doing

\footnotetext{
$4 \quad$ See von Wright, 1982, pp. 163-182. This essay was first published in 1972 and presented in a conference already in 1970, i.e. almost immediately after the publication of On Certainty in 1969, and it remains one of the most thoughtful discussions of On Certainty. On the recent "pragmatist" debates on On Certainty, see Moyal-Sharrock, 2003, 2004a and 2004b, as well as Pihlström, 2012.

5 Huw Price's work on causation might be seen as coming close to von Wright's, because Price (2011, p. 31) also suggests that "uses of causal concepts in science" might reflect the "agentive perspective".
} 
things and intentionally interfering with the course of nature" (von Wright, 1971, pp. 65-66). More precisely, the connection between causation and action is spelled out as follows: " $p$ is a cause relative to $q$, and $q$ an effect relative to $p$, if and only if by doing $p$ we could bring about $q$ or by suppressing $p$ we could remove $q$ or prevent it from happening" (von Wright, 1971, p. 70). Thus, by manipulating the cause we can, in principle, bring about the effect; this is of course crucial in scientific experimentation.

In a slightly later work, von Wright (1974) specifies the theory while connecting it to the issue of determinism. The leading argument is that " $[t]$ he idea that causal connections are necessary connections in nature is rooted in the idea that there are agents who can interfere with the natural course of events" (von Wright, 1974, pp. 1-2). In our conceptual order, so to speak, action is the primary concept and causation the secondary one (von Wright, 1974, p. 2). The conclusions he eventually arrives at regarding the determinism vs. indeterminism dispute are not ontological or metaphysical either, but rather of a conceptual or epistemic nature (see von Wright, 1974, p. 136). ${ }^{6}$

This theory of causation, which (as some commentators have observed) comes interestingly close to the "interventionist" developments in contemporary discussions of causality and explanation (e.g., Woodward, 2003), has often been criticized because it seems to make causation "human-centered" in a problematic way. The relations between cause and effect seem to be relative to what we can, or could, manipulate and what we cannot. However, von Wright makes it clear that he is not aiming at an anthropocentric metaphysics of causation, even though he maintains that "to think of a relation between events as causal is to think of it under the aspect of (possible) action" (von Wright, 1971, p. 74). This is only a matter of how we must think, or how we must organize our concepts; it does not mean that there is any genuine agency involved in causation (von Wright, 1971, p. 73). "Causation operates throughout the universe-also in spatial and temporal regions forever inaccessible to man" (von Wright, 1971, p. 73). Von Wright (1974, pp. 48-50) makes this more precise by saying that while causation is conceptually dependent on agency, it is "ontically independent of agency" (von Wright, 1974, p. 49; original emphasis). The "conceptual" dependence

Von Wright (1974, p. 136) concludes: "To say that to establish the ontic certainty of a change presupposes an epistemic certainty $[\ldots]$ is but another way of saying that establishing causal bonds in nature presupposes action. It is by virtue of these relationships that I say that the concept of cause presupposes the concept of action. Action, however, cannot rightly be said to presuppose the existence of ontic alternatives in nature, i.e. the truth of some form of indeterminism. What action presupposes is only the epistemic certainty which, as long as it is not undermined, entails the belief in the ontic contingency of some changes and thus takes for granted a certain margin of indeterminism in the world." 
lies between "the notion of a (causal) counterfactual conditional and action", instead of lying directly between cause and action (von Wright, 1974, p. 50). Thus, in brief, "the concept of causal connection rests on the concept of action" (von Wright, 1974, p. 53; original emphases). In any event, this conceptual link does connect von Wright's views with pragmatism: our world-picture generally, including our conception of causal relations in particular, must be thought of in terms of, or on the basis of, our conception of our own agency. ${ }^{7}$

Secondly, while causation must be thought of in terms of, or "under the aspect of", possible action, human actions cannot, according to von Wright, be simply causally explained. To attempt to do so would be to commit a kind of category mistake. Von Wright's (1971; 1980; 1998) "non-causalist" (as we might say) conception of action, agency, and freedom-and their proper explanation-is arguably more relevant in contemporary philosophy of mind and action than has been so far acknowledged by mainstream philosophers in these fields. Von Wright has consistently opposed attempts to reduce intentionality or agency to a causal, natural-scientific picture of the world. ${ }^{8}$ The concept of freedom, in particular, cannot be accommodated in such a picture. Denying that agents are free would be "to commit a contradiction in terms", while the "mystery" of human freedom is nothing more than the "mystery" that "there are agents

\footnotetext{
Regarding this deep connection between the ways we talk and think about the world generally and the ways we talk and think about human agency, it might be speculated that von Wright's later views on the conceptual dependence of causation on action might be partly based on, or at least parallel to, his earlier idea_originated during his Cambridge years (1948-1951), leading up to his pioneering work on modal and deontic logic, with the first publications in the early 1950s - that there is an analogy between the ways in which the standard quantifiers of predicate logic, on the one hand, and the modalities and deontic modalities, on the other hand, behave. Thus, our basic logical concepts "some", "all", and "no" can be seen as functioning in ways analogous to modal concepts ("possible", "necessary", and "impossible") and deontic ones (“allowed”, "obligated”, "forbidden”). Von Wright (2001, p. 179) tells us that this came to him as a sudden insight when he was walking along the river Cam (presumably around 1950). However, this is only a speculative analogy. Yet, given von Wright's exposition to Wittgenstein's developing views, it is not implausible to suggest that von Wright could have seen a profound connection between certain uses of words, or logical vocabularies. This might be described as an insight into the similarities of certain language-games, or their logical structures (keeping in mind that Wittgenstein himself in his late period did not focus on hidden "deep" structures of language-games but on what we actually do with our language, nothing being hidden). In this sense, von Wright's thought is, as so often, both Wittgensteinian and nonWittgensteinian, more original than some other "Wittgensteinians" work.

8 On the relevance of von Wright's "actionistic" account of causation for an "anti-naturalistic" "humanization of nature", bringing von Wright close not only to Wittgenstein but also to Edmund Husserl; see Egidi, 1999, especially pp. 4-5. Obviously we could add pragmatist thinkers, particularly James, to this list, but this would require some qualifications: the pragmatists are generally naturalists, but their naturalism is never reductive but always already "humanized"; see Pihlström, 2003. Rosa M. Calcaterra is one of the very few scholars explicitly comparing von Wright's theory of action and (James's) pragmatism, pointing toward a "non-causalistic" theory of action and an "emancipation of the discussion about human freedom from traditional epistemological and ontological approaches" (Calcaterra, 1999, p. 139). See Egidi’s (1999) volume more broadly for several investigations of von Wright's views on action (among other things) and their significance for "humanistic" philosophy.
} 
and actions" (von Wright, 1980, pp. 77-78). Freedom, then, is a fully nonmysterious feature of agency based on our ability to understand human beings as persons and to rationally explain their actions on that basis. No non-natural causal connections between the mental and the physical are assumed, because intentions are reasons, not causes; there is no need to postulate such Cartesianlike interactionist causation, according to von Wright (1998, p. 109). As Rosaria Egidi (2009) emphasizes, von Wright shares with Deweyan pragmatism the reconciliatory desire to develop a worldview rich enough for both human agency and natural science-a "naturalistic humanism".?

Thirdly, von Wright might be read as a pragmatic pluralist not only in his theory of explanation but also at a metaphilosophical level. He defends a conceptual and explanatory pluralism according to which our different levels of inquiry and explanation, or different perspectives of description and conceptualization (i.e., the neural, the behavioral, and the mental or psychological), each have their own roles to play in our overall understanding of human experience and action. These different schemes, "vocabularies" (as a Rortyan pragmatist would prefer to put it), or language-games (in more explicitly Wittgensteinian terms) are each legitimate for their own purposes - just like the two essentially different modes of explanation, the causal and the intentional (teleological), investigated in von Wright's seminal work on explanation and understanding (von Wright, 1971). When explaining any event taking place in the world, we must always explain it under some description, first conceptualizing and thereby understanding it either as a natural event to be causally explained or as a human action with meaning, to be intentionally, rationally, and hence teleologically explained. In this sense, explanation - and even the notion of causation insofar as it is involved in causal explanations, in contrast to intentional or teleological explanations-is interest-relative (as is, of course, intentionality or teleology, as well). ${ }^{10}$

As von Wright (2001) explains in his autobiography, he later came to resist the term 'humanism', though.

10 At this point, we might even speak about von Wright's fundamental Kantianism. Just like Kant sought to reconcile the "worlds" of causally determined nature and of human action with moral responsibility, von Wright investigates the pragmatic interest-relativity of different explanations of the "same" world under different aspects. Insofar as this is also a Wittgensteinian position, this observation adds a new dimension to the proposal that Wittgenstein is (also) a fundamentally Kantian thinker. Furthermore, if the same compatibility of nature and freedom-determinism and moral responsibility - is also a pragmatist theme, Kantianism, Wittgensteinianism, and pragmatism seem to converge on this key issue. 


\section{The disunity of science}

This theme becomes extremely important in von Wright's later work on the philosophy of mind (von Wright, 1998), which is much less known and appreciated among philosophers today than his action-theoretical investigations from the 1960s and 1970s. ${ }^{11}$ The difference to pragmatism proper, however, is that the different schemes, vocabularies, or language-games that von Wright distinguishes and whose irreducibility he defends are not all ontologically relevant in the same way. While rational (intentional) explanations of actions, referring to reasons instead of causes (von Wright, 1998, pp. 19-20, 38-39), can be said to be epistemically prior to behavioral and neural explanations, because mental (psychological) states are epistemically prior to neural (physiological) states, and while behavior in turn can be regarded as semantically prior to mental states, because the content of mental states is available only through observations of outward actions, ${ }^{12}$ neural processes within the organism are, von Wright admits, causally prior to behavior. ${ }^{13}$ Thus, there is a sense in which the neural or neuro-physiological processes giving rise to certain behavior are ontologically fundamental in comparison to everything else in human action and agency. The pluralism of relevant conceptualizations and explanations is not to be conflated with ontological pluralism.

This is a key contrast to, say, Hilary Putnam's $(1995 ; 2002)$ conceptual relativity and pragmatic pluralism-or to William James's ([1907]1975) pluralistic constructivism, according to which objects themselves arise out of human purposive practices. ${ }^{14}$ I would be tempted to add that this is also a somewhat un-Wittgensteinian dimension in von Wright's pluralism. If any ontological or metaphysical inquiry can be said to be possible or acceptable in Wittgenstein's philosophy at all, Wittgenstein would presumably resist the conclusion (or, rather, assumption) that some schemes, vocabularies, perspectives, or languagegames are ontologically serious while some others are not. The very distinction von Wright relies on in his theory of causation, that is, the distinction between, as we may say, the ontological order of the world and the conceptual order of our ways of thinking about the world-a distinction crucially manifested in von

11 I am here indebted to Antti Kuusela's (2010) recent work on von Wright's philosophy of mind, with comparisons to not only Wittgenstein but also Donald Davidson.

12 The mental, von Wright (1998, p. 162) tells us, is "the meaning of complex patterns of bodily reactions".

13 Or, in a nutshell: the action, according to von Wright (1998, p. 142), is the bodily movement "viewed under the aspect of intentionality"; the muscular activity and the action share the same "robust reality" while being differently described and conceptualized (von Wright, 1998, pp. 34-35).

14 See also Pihlström, 2009 for some developments of these versions of pragmatism. 
Wright's contention that while the concept of causation presupposes the concept of agency, causation itself, as operative throughout nature, is independent of actions and agents—is, for a pragmatist, precisely the problematic starting-point of metaphysical realism that leads to philosophical difficulties. Both classical pragmatists like James (and even Peirce and Dewey, suitably interpreted) and neopragmatists like Putnam would argue, in opposition to this distinction, that we can have access only to a world that we have conceptualized from the perspectives of our practice-embedded categorial (categorizing) frameworks or language-games. Hence, the distinction between ontic (ontological) and epistemic (conceptual) conclusions regarding indeterminism to be drawn from von Wright's (1974) application of the theory of causation to the determinism vs. indeterminism issue might also be argued to be problematic from a pragmatist perspective. $^{15}$

Even so, von Wright in his later work arrived at a view denying the unity of the scientific worldview-maintaining that there is an irreducible plurality in our descriptions and explanations of reality in the sense sketched above-and this endorsement of the "disunity" of science may be seen as a truly pragmatist theme in his work. At least von Wright joins the pragmatists, classical and contemporary, in resisting any reductive physicalism about human action and culture. ${ }^{16}$

There is, furthermore, one interesting remark in von Wright's Wittgenstein, in the essay on Wittgenstein on certainty, that connects von Wright's interpretation of Wittgenstein with his theory of action and explanation. Having examined at some length On Certainty and Wittgenstein's conception of the "non-propositional" or "pre-propositional" character of the "world-picture" and forms of life underlying our language, he observes: "But in order that my behaviour should be describable as actions of a certain kind, it must be interpreted in terms of the notions of the language-game itself. So, to this extent the praxis at the basis of the languagegame is a pre-praxis, one could say, and not yet a full-fledged action." (Von Wright,

15 While a pragmatic criticism of the distinction between the ontological and the conceptual has been part and parcel of my own approach to pragmatism since the 1990s up to my more recent reflections on pragmatism (Pihlström, 2009; 2011), the claim about our ontologies being relative to, or dependent on, our conceptualizations and categorizations must of course be heavily qualified and modified in order to make it philosophically sustainable. For an attempt to contextualize the very distinction between schemeor practice-dependence and -independence, see Pihlström, 2011. The crucial move here is a quasi-Kantian retranscendentalized account of pragmatism.

16 Von Wright's view on causation has also inspired, among others, Karl-Otto Apel (cf. 1998, pp. 22-23, 133). The "interventionist" position has been important for Apel as a background idea in his defense of critical hermeneutics and "transcendental pragmatism" in the Erklären vs. Verstehen controversy; see also Wallgren, 2003, p. 543. Apel was enormously influential in bringing pragmatism (especially Peirce) to Germany and Europe; yet, his heavily Kantian transcendental pragmatics of language is not equivalent to Wittgensteinian "transcendental pragmatism". 
1982, p. 179) This is a profound remark. We too easily speak about action lying at the basis of our language-games, or about "deed" being "in the beginning". Wittgenstein himself says things of this kind. But actions, properly speaking, are something that are always already conceptualized-they have reasons. They can be conceptualized and understood only within a language-game. Hence, the "action" that incorporates and manifests our most fundamental (yet, as we have seen, revisable) certainties - the action constituting our "hinges" — cannot really be action in this sense. The non-propositional hinges enabling language-games and meaning are not themselves meaningful; in the same sense, the actions manifesting those hinges are not proper actions. In this pre-praxis, we might say, we follow rules blindly and our "spade is turned" (cf. Wittgenstein, 1953, \$217).

To take a von-Wrightian example: it belongs to my "pre-praxis", to my fundamental certainties ("hinges"), that I do not first make sure that I still have my two hands before engaging in the proper "praxis" or action of opening the window (manifested in a certain kind of outward behavior) with the intention of cooling the room. However, once again, just as the pragmatist insisting on beliefs and other propositional states being "habits of action" should resist essentialist dichotomies between the propositional and the non-propositional (as argued in Pihlström, 2012), s/he might also resist this division of human behaviors into proper actions and (a kind of) pseudo-actions, or the corresponding division of our activities into proper praxis and pre-praxis. There is, arguably, a continuity here instead of any sharp separation reflecting an essentialistic difference. The very notion of a habit of action can be employed to highlight this continuity. ${ }^{17}$

\section{Public philosophy}

Finally, the fourth dimension of von Wright's so-called pragmatism is presumably better known to his Finnish and Scandinavian colleagues and followers than to his international academic audience. In his home country Finland, he was a widely

\footnotetext{
${ }_{17}$ The issue of continuity is also related to the question concerning the possible intentionality (or lack thereof) of the actions or behaviors of higher animals. Is there an evolutionary continuity here or a fundamental difference between our intentional actions and the purely causally explainable non-intentional (though possibly intentional-seeming) behavior of animals? I must here leave this question untouched, but I should like to note that the difference between those who find human beings essentially different from animals in this regard and those who find them not essentially different but only very different - that is, see them continuous yet very far from each other regarding capacities for reasoned action-may itself be a problematic distinction, or even a distinction without (pragmatic) difference. The pragmatic method could perhaps be employed here in order to show that there is no conceivable difference in the potential practical effects of these only apparently different views.
} 
respected "public philosopher" in a manner perhaps comparable to, say, Dewey in the United States or even Jean-Paul Sartre in France and Jürgen Habermas in Germany. Probably his best known work in this area is Vetenskapen och förnuftet ('Science and Reason'; von Wright, 1986), which criticizes the self-destructive tendencies of Western civilization, particularly the way in which human reason itself, through its scientific and technological advances and applications, has driven the world close to ecological destruction. ${ }^{18}$

This, however, is not a particularly Wittgensteinian aspect of his "pragmatism", even though von Wright's cultural pessimism itself is partly derived from Wittgenstein as well as, among others, Oswald Spengler. Yet, it can hardly be forbidden for a Wittgensteinian thinker to be active in public issues such as environmental problems, social policy, or war and peace. Indeed, von Wright himself also wrote an essay on Wittgenstein in relation to "his times", that is, as a thinker engaged in a cultural diagnosis of what is going on in the world beyond academic philosophy. ${ }^{19}$ Wittgenstein, of course, was very far from being a public philosopher; yet, von Wright as a publicly well-known figure commenting on deep issues of human civilization clearly shared his teacher's cultural pessimism. Neither Wittgenstein nor von Wright felt completely "at home" in the world and culture they lived in.

Von Wright's case demonstrates that one can be a pragmatist in many different ways. Here we can see Wittgensteinian contextuality and family resemblance at work again. For a pragmatic pluralist, there is a plurality of practice-embedded ways of being a pragmatist in one's philosophical activities. One can, moreover, be a pragmatist in "first-order" issues but also in "second-order" or meta-level ones, or in both. There is very little we find in von Wright's thought that can be directly linked with pragmatism, but at the meta-level there is, in fact, a lot. ${ }^{20}$

18 Some of von Wright's "cultural" writings of this kind have been translated into English: see von Wright, 1993. Here I am not even trying to summarize his profound views on "the myth of progress", the selfdestructiveness of human reason, and cultural pessimism. Von Wright's career as a cultural discussant did not begin with his politically engaged comments in the 1960s but goes back to his early essays in the 1940s on Dostoevsky and Tolstoy.

19 See the essay "Wittgenstein in Relation to His Times" (von Wright,1982, pp. 203-216).

20 An early version of this paper was presented as a part of my more comprehensive paper on Wittgenstein and pragmatism in the workshop, "Cambridge Pragmatism", at Trinity College, University of Cambridge, UK, in June, 2012. (The larger part of my contribution, focusing on Wittgenstein, is published as Pihlström, 2012, but there is no overlap between the two papers.) Thanks are due to Huw Price in particular and the audience for valuable comments. I should also like to thank Peeter Müürsepp for the kind suggestion to submit this paper to this journal. 


\section{References}

Apel, K.-O. (1998), From a Transcendental-Semiotic Point of View, ed. by M. Papastephanou, Manchester: Manchester University Press.

Calcaterra, R. M. (1999), "W. James' Defence of Free Will: A Step toward a Paradigm Shift," in R. Egidi (ed.) In Search of a New Humanism: The Philosophy of Georg Henrik von Wright, Dordrecht: Kluwer, pp. 139-146.

http://dx.doi.org/10.1007/978-94-017-1852-3_15

Egidi, R. (1999), "Von Wright and 'Dante's Dream': Stages in a Philosophical Pilgrim's Progress," in R. Egidi (ed.) In Search of a New Humanism: The Philosophy of Georg Henrik von Wright, Dordrecht: Kluwer, pp. 1-34. http://dx.doi.org/10.1007/978-94-017-1852-3_1 http://dx.doi.org/10.1007/978-94-017-1852-3

_ (2009), "Von Wright's Philosophical Humanism," European Journal of Pragmatism and American Philosophy, vol. 1, no. 1, pp. 1-8.

Goodman, R. B. (2002), Wittgenstein and William James, Cambridge: Cambridge University Press. http://dx.doi.org/10.1017/CBO9780511498138

Hartshorne, C. (1989), "Von Wright and Hume's Axiom," in P. A. Schilpp \& L. E. Hahn (eds.) The Philosophy of Georg Henrik von Wright, La Salle, IL: Open Court, pp. 59-76.

James, W. ([1907]1975), Pragmatism: A New Name for Some Old Ways of Thinking, ed. by F. H. Burkhardt, F. Bowers and I. K. Skrupskelis, Cambridge, MA \& London: Harvard University Press.

Kuusela, A. (2010), Non-reductive Physicalism, Irreducibility of the Mental and the Problem of Mental Causation: A Study of Donald Davidson's and Georg Henrik von Wright's Positions in the Philosophy of Mind, PhD Diss., Department of Philosophy, University of Helsinki. Retrieved from http://www.doria.fi/handle/10024/64338 [accessed March 2014]

Moyal-Sharrock, D. (2003), "Logic in Action: Wittgenstein's Logical Pragmatism and the Impotence of Scepticism," Philosophical Investigations, vol. 26, no. 2, pp. 125-148.

(2004a), Understanding Wittgenstein's On Certainty, Basingstoke: Palgrave Macmillan.

, ed. (2004b), The Third Wittgenstein: The Post-Investigations Works, Aldershot: Ashgate.

Moyal-Sharrock, D. \& Brenner, W. H., eds. (2007), Readings of Wittgenstein's On Certainty, Basingstoke: Palgrave Macmillan.

http://dx.doi.org/10.1111/1467-9205.00291

Pihlström, S. (2003), Naturalizing the Transcendental: A Pragmatic View, Amherst, NY: Prometheus/Humanity Books. 
- (2009), Pragmatist Metaphysics: An Essay on the Ethical Grounds of Ontology, London \& New York: Continuum.

_ - ed. (2011), The Continuum Companion to Pragmatism, London \& New York: Continuum.

(2012), "A New Look at Wittgenstein and Pragmatism," European Journal of Pragmatism and American Philosophy, vol. 4, no. 2, pp. 9-26. Retrieved from http:// lnx.journalofpragmatism.eu/ [accessed Mar 2014]

Price, H. (2011), Naturalism without Mirrors, Oxford \& New York: Oxford University Press.

Putnam, H. (1995), Pragmatism: An Open Question, Oxford \& Cambridge, MA: Blackwell.

- (2002), The Collapse of the Fact/Value Dichotomy and Other Essays, Cambridge, MA \& London: Harvard University Press.

Schilpp, P. A. \& Hahn, L. E., eds. (1989), The Philosophy of Georg Henrik von Wright, La Salle, IL: Open Court.

Wallgren, T. (2003), 'Critical Theory', in L. Haaparanta \& I. Niiniluoto (eds.) Analytic Philosophy in Finland, Poznan Studies in the Philosophy of the Sciences and Humanities 80, Amsterdam: Rodopi.

Wittgenstein, L. ([1953]1958), Philosophical Investigations, transl. by G. E. M. Anscombe, Oxford: Basil Blackwell.

(1969), On Certainty, ed. by G. E. M. Anscombe \& G. H. von Wright, transl. by G. E. M. Anscombe \& Denis Paul, Oxford: Basil Blackwell.

_ (1980), Culture and Value, ed. by G. H. von Wright, transl. by Peter Winch, Chicago: University of Chicago Press.

Woodward, J. (2003), Making Things Happen: A Theory of Causal Explanation, Oxford: Oxford University Press.

von Wright, G. H. (1943), Den logiska empirismen, Helsingfors: Söderströms. (1971), Explanation and Understanding, Ithaca, NY \& London: Cornell University Press.

(1974), Causality and Determinism, New York \& London: Columbia University Press.

(1980), Freedom and Determination, Acta Philosophica Fennica, vol. 31, no. 1, Helsinki: The Philosophical Society of Finland.

— (1982), Wittgenstein, Oxford: Basil Blackwell. (1986), Vetenskapen och förnuftet, Stockholm: Bonnier.

(1993), The Tree of Knowledge, Leiden: Brill.

(1998), In the Shadow of Descartes: Essays in the Philosophy of Mind, Dordrecht: Kluwer. http://dx.doi.org/10.1007/978-94-015-9034-1

(2001), Mitt liv som jag minns det [My Life as I Remember It], Stockholm: Bonniers. 
Sami Pihlström received his PhD degree in theoretical philosophy from the University of Helsinki in 1996. In 2006-2014, he was Professor of Practical Philosophy at the University of Jyväskylä, Finland. He is also, since 2009, the Director of the Helsinki Collegium for Advanced Studies at the University of Helsinki; in 2014 he was appointed to a Professorship in the Philosophy of Religion at the University of Helsinki. He has published widely on pragmatism, the problem of realism, metaphysics, ethics, philosophical anthropology, and the philosophy of religion. His recent books include Pragmatist Metaphysics (Continuum, 2009), The Continuum Companion to Pragmatism (ed., Continuum, 2011), Transcendental Guilt (Lexington Books, 2011), and Pragmatic Pluralism and the Problem of God (Fordham University Press, 2013), as well as the essay collection, William James on Religion, co-edited with Henrik Rydenfelt (Palgrave, 2013). 